\title{
Combining Ability Analysis and Genetic-Effects Studies for Some Important Quality Characters in Brassica napus L.
}

\author{
Aamar Shehzad $^{1 *}$, Hafeez Ahmad Sadaqat ${ }^{1}$, Mohsin Ali ${ }^{2}$, Muhammad Furqan Ashraf ${ }^{3}$
}

${ }^{I}$ Department of Plant Breeding and Genetics, University of Agriculture Faisalabad.

${ }^{2}$ Department of Plant Pathology, University of Agriculture Faisalabad.

${ }^{3}$ College of Crop Science, Fujian Agriculture and Forestry University, Fuzhou-350002, China

\section{A R T I C LE I N F O}

\section{Article history:}

Received 05 June 2015

Accepted 14 September 2015

Available online, ISSN: 2148-127X

\section{Keywords:}

Brassica napus L.

Combining ability

Genetic effects

Quality

${ }^{*}$ Corresponding Author:

E-mail: aamarshehzad1763@gmail.com

\section{A B S T R A C T}

Combining ability analysis has an important position in rapeseed breeding. To evaluate genetic and combining ability effects, three Brassica napus L. testers "Punjab Sarson, Legend and Durre-NIFA" and five lines "Duncled, K-258, ZN-R-1, ZN-R-8, ZN-M-6" were crossed using line $\times$ tester design in Randomized Complete Block Design (RCBD) with three replications. Mean sum of squares of the analysis of variances (ANOVA) for genotypes was highly significant for all of the traits. Most of the lines and testers exhibited significant results of mean sum of squares for combining ability. Line 'Duncled' was proved good general combiner for oil (8.8), protein (3.7), erucic acid (33.0), oleic acid (13.0) and glucosinolate (-19.3) over other lines and tester 'DurreeNIFA' for protein (6.6), erucic acid (-23.4), and linolenic acid (-5.3) over other testers. Significant specific combining ability effects were also observed. The best hybrid combinations were Legend $\times$ ZN-R-1 for oil (9.6), Punjab Sarson $\times$ Duncled for minimum erucic acid (-14.0) and linolenic acid contents $(-6.0)$, and Legend $\times \mathrm{ZN}-\mathrm{M}-6$ for maximum protein (8.2) and minimum glucosinolate contents $(-11.1)$. The maximum oil contents were observed in 'Legend $\times$ ZN-R-1' (52.4\%). The cross 'Punjab Sarson $\times$ Duncled' expressed maximum values of protein $(26.5 \%)$ and oleic acid $(62.5 \%)$ while minimum for erucic acid (2.3\%), linolenic acid (5.4\%) and glucosinolate contents $(19.3 \mu \mathrm{mol} / \mathrm{g})$. This research discloses the significance of non-additive genetic effects for most of the studied traits except oil contents. These studies will also help to improve nutritional values of rapeseed crop by selecting noble crosses.

\section{Introduction}

Pakistan is an agricultural country and proceeding relatively better in main crops over oilseed crops. During 2013-14, local production of edible oil was 26 percent (0.606 million tons) and import was 74 percent (1.719 million tons) of worth Rs.148.633 billion. The population of Pakistan is growing promptly with $1.95 \%$ growth rate which is faster than the average growth rate of South Asian countries (Pak. Economic Survey, 2013-14). Pakistan has been gifted with different seasons and productive soil to raise vital oil seed crops - sunflower, canola, olive and oil palms. So, it is crucial to breed and grow oilseed crops to feed rapidly growing population. It will also help us to earn millions of rupees by exporting edible oil to other nations.

Rapeseed comprises of Brassica napus L. and Brassica rapa. It is a vital source of edible oil for the world. It is a second chief source of protein meals and has third position in world production (Azizinia, 2012). The leading rapeseed-producing states are Canada, China, India and France (FAOSTAT-2012).

Brassica napus L. is an important oilseed crop in
Pakistan and all over the world. The total seed composition of Brassica species differs largely and depends upon genetic e.g. variety, species, cultivar as well as environmental factors i.e. water, temperature and nutrient supply. It contains $36-50 \%$ oil contents mainly used for cooking and margarine and 33 to $48 \%$ protein contents, which are used in animal and poultry feed (Snowdon et al., 2007). It is raised for young leaves to use as herb, forage to feed livestock and rapeseed oil used in food industry as well as in soap industry (Noor-UlAbideen et al., 2013). The quality of Brassica oil depends upon the important constituents i.e. protein, oleic acid, erucic acid, glucosinolate, linolenic acid and moisture contents. For edible purpose, high concentration of protein, oleic acid and low amount of erucic acid, glucosinolate and linolenic acid are beneficial (Ahmad et al., 2012). Rapeseed oil with low percentage of erucic acid is acceptable for cooking and margarine but high concentration of erucic acid in oil is a health risk. High ratio of erucic acid is crucial for manufacturing industrial products i.e. lubricants, plasticizer, surface active agents, 
waxes and water repellents (Bhardwaj and Hamama, 2000 and Burns et al., 2003). High quantity of glucosinolate in oil causes goitrogenic disorder. In edible oil, glucosinolates must be present less than $30 \mu \mathrm{moleg}^{-1}$ or even lower than it (Snowdon et al., 2007). High level of linolenic acid causes the phenomenon of oxidation which affects the quality and flavor of oil and oil becomes unhealthy for human consumption. Low quantity of linolenic acid affects positively and is required for normal vascular and immunological system control (Burns et al., 2003). So, it is essential to breed varieties of oilseed Brassica with low level of linolenic and erucic acid for human consumption.

Combining ability analysis is an important breeding method and delivers facts related to desirable parents, magnitude and nature of gene action which control the quantitative characters (Ceyhan et al., 2008). Line $\times$ tester analysis is used to find out combining abilities of bulk crossed experimental materials i.e. general combining ability (GCA) and specific combining ability (SCA). Information related to GCA and SCA effects is compulsory for designing the next cycle of a breeding program (Turi et al., 2010). Many scientists had been used line $\times$ tester analysis to examine genetics of agromorphological characters and judgment of GCA and SCA effects in sunflower (Khan et al., 2009), cotton (Panhwar et al., 2008), pea (Ceyhan et al., 2008), wheat (Saeed et al., 2001) and Brassica (Rameeh, 2011 and Farshadfar et al., 2013). The recent research is intended to investigate the worth of lines, testers and hybrids for oilseed controlling characters by applying line $\times$ tester method.

\section{Materials and Methods}

The experimental material consisted of eight Brassica napus L. genotypes named Duncled, K-258, ZN-R-1, ZNR-8, ZN-M-6, Punjab Sarson, Legend and Durre-NIFA. These parental materials were obtained from germplasm collection of the Department of Plant Breeding and Genetics, University of Agriculture, Faisalabad. During October 2012-13, five lines "Duncled, K-258, ZN-R-1, ZN-R-8, ZN-M-6" and three testers "Punjab Sarson, Legend and Durre-NIFA" were sown and crossed manually in line $\times$ tester design to obtain crossed seeds of 15 hybrids. Seeds of eight parents and 15 crosses were laid out in Randomized Complete Block Design (RCBD) with three replications during October 2013-14. All the entries were randomized in each replication. Each entry was sown in plot having dimension $3 \mathrm{~m} \times 10 \mathrm{~m}$. The plant to plant distance was $30 \mathrm{~cm}$, and row to row distance was $60 \mathrm{~cm}$. Thinning between younger plants was done to maintain recommended plant to plant distance. Recommended dose of NPK fertilizers were used (Azizinia, 2012). Plant protection approaches were applied to keep the experimental crop healthy. At the maturity stage of $F_{1}$ hybrids, ten plants of each parent and hybrid from each plot were randomly chosen to collect $F_{2}$ seeds for recording data of 15 characters. Data were subjected to analysis of variance to evaluate the significance differences among $F_{1}$ hybrids and their parents (Steel et al., 1997). Line $\times$ tester analysis was used to estimate general combining ability and specific combining ability (Kempthorne, 1957). Data were taken for traits i.e. oil, protein, erucic acid, oleic acid, glucosinolate, linoleic acid, linolenic acid contents and analyzed on Near-Infrared Reflectance (NIR) spectroscopy (FOSS 6500 equipped with ISI version 1.02 a software of Infra Soft International) at biochemical laboratory, crop breeding section of Nuclear Institute for Food and Agriculture (NIFA) Peshawar (Ahmad et al., 2012). Statistical software (TNAUSTAT statistical package: $\mathrm{L} \times \mathrm{T}$ analysis with parents) was used to calculate ANOVA, general and specific combining ability (https://sites.google.com/site/tnaustat/plant-breedingheterosis).

\section{Results and Discussion}

\section{Oil contents (\%)}

In analysis of variance, highly significant $(\mathrm{P} \leq 0.01)$ results were notified by all parents (both lines and testers), crosses and lines $\mathrm{x}$ tester interactions. Female genotypes Duncled, K-258, ZN-R-8 and ZN-M-6 revealed significant GCA in positive and negative direction for oil contents except ZN-R-1 which is showed in Table 1. The tester Punjab Sarson revealed highly significant results for GCA (-3.6) followed by Legend in (2.4). According to the results of Table 2, six hybrid genotypes revealed significant SCA effects in positive direction and also six in negative direction. Three hybrids showed nonsignificant SCA effects. The hybrid 'Legend $\times$ ZN-R-1' showed highest desired SCA effects (9.6) for oil contents followed by 'Punjab Sarson $\times$ Duncled' (5.1). Turi et al. (2010) conducted his experiment in Brassica juncea and found desirable GCA effects (1.07 and 1.05) for NUM124 and NUM113. Crosses 'NUM113 x NUM105' and 'NUM124 x NUM120' also showed significant SCA (2.63 and 1.74) for oil contents respectively. Sabaghnia et al. (2010) also calculated similar results and exhibited highly significant GCA for five lines while 21 crosses also showed highly significant SCA effects.

Nasim and Farhatullah (2013) expressed his results in which two lines indicated significant GCA effects. Maximum positive GCA (1.04) was showed by ACC-403. Four crosses revealed positive SCA results. The hybrids ACC-403 x ACC-1500 and ACC-265 x ACC-909 showed maximum SCA effects (2.72 and 2.87). According to the results the mean values of oil contents in fifteen crosses were $49.42 \%$. The cross 'Legend $\times$ ZN-R-1' showed highest (52.4\%) while 'Punjab Sarson $\times$ ZN-R-1' revealed lowest oil contents (46.8\%). Ping et al. (2003) found range of oil contents $36-46 \%$ and defined significant variation for oil contents. Noor-Ul-Abideen et al. (2013) and Azizinia (2012) found nearby the same results of oil contents with mean $51.1 \%$ and range 42.7 to $53.3 \%$ in Brassica napus L. Ahmad et al. (2012) calculated the range from 42.73 to $52.10 \%$ oil contents which is close to our study. Bhardwaj and Hamama (2000) predicted $37.4 \%$ mean oil contents with 29.6$49.2 \%$ range which are slightly lower than this study. The variation in results might be due to the effects of genotypes, soil and environmental condition. 


\section{Protein contents (\%)}

According to results of analysis of variance for protein contents, genotypes, parents, crosses, lines, testers and their interactions ( $\mathrm{L} \times \mathrm{T}$ ) manifested highly significant $(\mathrm{P} \leq 0.01)$ genetic variation. One female line "Duncled" showed highly significant effects of GCA (3.7). Tester (Punjab Sarson) depicted negative significant result of GCA (-2.1) while testers (Durre-NIFA and Legend) noticed highly significance GCA effects (6.6 and -4.5) respectively for protein contents.

In the case of specific combining ability effects (Table 2), twelve hybrids out of fifteen, showed significant/highly significant effects for SCA. "Legend $\times$ ZN-M-6" hybrid depicted highest significant effect for GCA (8.2) followed by "Punjab Sarson $\times$ Duncled" (8) and "Legend $\times \mathrm{ZN}-\mathrm{R}-8$ " (5.4). The hybrid "Punjab Sarson $\times$ ZN-R-8" expressed highest SCA effects in negative direction (-9.6) followed by "Legend $\times$ Duncled" $(-8)$ and "Legend $\times$ ZN-R-1" (-6.7). Turi et al. (2010) found significant results of GCA (0.68) for genotype NUM120 and SCA (-1.41) for cross NUM113 x NUM105. Ahmad et al. (2012), Girke et al. (2012), Nasim and Farhatullah (2013) and Noor-Ul-Abideen et al. (2013) assessed the significant effects of GCA and SCA for protein contents.

The protein contents of the fifteen Brassica genotypes displayed that protein contents present in 'Punjab Sarson $\times$ Duncled' $(26.5 \%)$ were the highest and lowest in 'Punjab Sarson $\times$ ZN-R-8' (19.5\%) with the mean values (23.27\%). Khan et al. (2008) and Ahmad et al. (2012) found the similar findings with 23.0 to $25.6 \%$ and 20.38 $25.12 \%$ protein contents respectively. Noor-Ul-Abideen et al. (2013) calculated protein percentage from 18.8 to 21.1 with the mean $19.7 \%$ that are little lower than present findings.

\section{Erucic acid (\%)}

In analysis of variance, genotypes, parents, crosses, parents vs. crosses, lines, testers and their interactions (L $\mathrm{x} T)$ showed highly significant $(\mathrm{P} \leq 0.01)$ variation.

All lines and testers revealed significant effects of GCA for erucic acid either in negative or positive direction. The highest significant GCA effects in negative direction were shown by "Duncled" followed by "DurreeNIFA" and "ZN-R-8".

In Table 1, all hybrids except two exhibited significant/highly significant effects of SCA in negative or positive direction for erucic acid. Hybrids with negative effects of SCA were selected because they possessed less amount of erucic acid that is good for human consumption. The hybrid "Punjab Sarson $\times$ Duncled" expressed highest SCA effects in negative direction (-14) followed by "Legend $\times$ ZN-M-6" $(-13.5)$ and "Legend $\times$ ZN-R-8" (-10.9). Lines NUM103 and NUM113 revealed desirable GCA effect (-4.89 and 3.93), while crosse NUM009 x NUM117 showed maximum SCA effects (-11.01) for erucic acid contents (Turi et al., 2010).

For edible oil, high contents of oleic acid, protein, and low glucosinolate, erucic acid and linolenic acid concentrations are essential (Ahmad et al., 2012). Rapeseed oil having low contents of erucic acid is mandatory for diet but high concentration has adverse effects on health. So, negative effects of GCA and SCA are desirable for erucic acid (Nasim and Farhatullah, 2013). The Erucic acid contents were highest $(53.2 \%)$ in the genotype 'Legend $\times$ ZN-R-1' and lowest $(2.3 \%)$ in 'Punjab Sarson $\times$ Duncled' with the mean values of $31.75 \%$. El-Beltagi et al. (2010) and Girke et al. (2012) determined the range of erucic acid contents $(0.15-86.5 \%)$ that are slightly higher than present studies $(2.3-53.2 \%)$. Noor-Ul-Abideen et al. (2013) evaluated results of their studies with range $(42.7-59.9 \%)$ and mean values $(51.0 \%)$. Khan et al. (2008) found erucic acid contents (48-59\%) in different genotypes of Brassica. Ahmad et al. (2012) calculated 36.44-56.2\% erucic acid contents in 12 Brassica genotypes. The above results of different researchers supported to the present findings.

Oleic acid (\%)

According to results of analysis of variance for oleic acid, genotypes, parents, crosses, lines, testers and their interactions $\left(\begin{array}{lll}\mathrm{L} & \mathrm{T}\end{array}\right)$ manifested highly significant $(\mathrm{P} \leq 0.01)$ genetic variation in experimental population of Brassica napus. Positive effects of GCA and SCA are desirable of oleic acid for industrial and nutritional usage (Nasim and Farhatullah, 2013). Three female lines (Duncled; K-258 and ZN-R-8) and two testers (Punjab Sarson and Legend) showed highly significant effects of GCA for percentage of oleic acid.

According to the results of Table 2, five hybrid combinations revealed significant SCA effects in positive direction and also five in negative direction. Five hybrids showed non-significant SCA effects. The hybrid 'Legend $\times$ K-2581' showed highest SCA effects in positive direction (4.3) for oleic acid contents followed by 'DurreNIFA $\times$ ZN-R-1 (3.8). "Punjab Sarson $\times$ ZN-M-6 and Legend $\times$ Duncled" hybrids revealed highest effects of SCA in negative direction (-5.1) followed by 'DurreNIFA $\times$ K-258' (-4.3). Turi et al. (2010) evaluated Indian mustard and found significant of GCA and SCA for line (NUM009) and crosses (NUM113 x NUM117, NUM103 $x$ NUM105 and NUM103 x NUM124).

Range of the values for oleic acid was $42.7 \%$ (DurreNIFA $\times$ K-258) to $62.5 \%$ (Punjab Sarson $\times$ Duncled $)$. The mean value of fifteen genotypes was $52.93 \%$ for oleic acid contents. In mustard rape, $9.2-61.0 \%$ oleic acid contents were observed by Snowdon et al., 2007. Ahmad et al. (2008) found the range of oleic acid concentration $(8.9-58.7 \%)$ that is approximately near to the present findings. Noor-Ul-Abideen et al. (2013) observed the similar results and found the range of oleic acid contents from 45.7 to $58.0 \%$ with mean values of $53.0 \%$. Ahmad et al. (2012) predicted oleic acid values form 29.93 to $54.74 \%$ which are slightly lower than present findings. Khan et al. (2008) also detected oleic acid in different genotypes of Brassica ranged from 38 to $49 \%$ with mean value of $42.25 \%$. 
Table 1 General combining ability effects of $\mathrm{F}_{2}$ seeds in Brassica napus L.

\begin{tabular}{l|ccccccc}
\hline Lines/characters & $\mathrm{O}$ & $\mathrm{P}$ & $\mathrm{EA}$ & $\mathrm{OA}$ & $\mathrm{GS}$ & LA & LNA \\
\hline Duncled & $8.8^{* *}$ & $3.7^{* *}$ & $-33.0^{* *}$ & $13.0^{* *}$ & $-19.3^{* *}$ & $10.9^{* *}$ & -1.3 \\
K-258 & $5.6^{* *}$ & -0.52 & $26.1^{* *}$ & $-8.8^{* *}$ & $-7.9^{* *}$ & $-6.1^{* *}$ & $4.2^{* *}$ \\
ZN-R-1 & 0.2 & -0.69 & $4.8^{* *}$ & -0.1 & $19.2^{* *}$ & $-3.4^{* *}$ & -0.3 \\
ZN-R-8 & $-7.5^{* *}$ & -0.74 & $-12.0^{* *}$ & $-3.6^{* *}$ & $12.5^{* *}$ & $4.4^{* *}$ & $-3.5^{* *}$ \\
ZN-M-6 & $-7.2^{* *}$ & -1.79 & $14.1^{* *}$ & -0.5 & $-4.4^{* *}$ & $-5.8^{* *}$ & 0.9 \\
Testers/Males & & & & & & \\
Punjab Sarson & $-3.6^{* *}$ & $-2.1^{*}$ & $7.0^{* *}$ & $-3.9^{* *}$ & $-3.9^{* *}$ & 1.2 & $3.1^{* *}$ \\
Legend & $2.4^{* *}$ & $-4.5^{* *}$ & $16.4^{* *}$ & $4.8^{* *}$ & 1.7 & -0.6 & $2.2^{*}$ \\
Durree-NIFA & 1.2 & $6.6^{* *}$ & $-23.4^{* *}$ & -0.9 & $2.2^{*}$ & -0.6 & $-5.3^{* *}$ \\
\hline
\end{tabular}

O: Oil; P: Protein; EA: Erucic acid; OA: Oleic acid; GS: Gluco-sinolate; LA: Linoleic acid; LNA: Linolenic acid; *=Significant at level of P $\leq 0.05$, $* *=$ Significant at level of $\mathrm{P} \leq 0.01$

Table 2 Specific combining ability effects of $\mathrm{F}_{2}$ seeds in Brassica napus L.

\begin{tabular}{|c|c|c|c|c|c|c|c|}
\hline Hybrids/characters & $\mathrm{O}$ & $\mathrm{P}$ & $\overline{\mathrm{EA}}$ & $\overline{\mathrm{OA}}$ & GS & $\mathrm{LA}$ & LNA \\
\hline Punjab Sarson $\times$ Duncled & $5.1 * *$ & $8.0^{* *}$ & $-14.0 * *$ & $3.4 * *$ & -1.5 & $6.4^{* *}$ & $-6.0 * *$ \\
\hline Punjab Sarson $\times$ K-258 & $-5.3 * *$ & $4.7 * *$ & $-7.7 * *$ & 0.0 & $2.7 * *$ & $-2.7 * *$ & 0.2 \\
\hline Punjab Sarson $\times$ ZN-R-1 & $-7.7 * *$ & 1.9 & $-2.9 * *$ & -0.5 & $-2.1 *$ & $-4.0 * *$ & $4.2 * *$ \\
\hline Punjab Sarson $\times$ ZN-R- 8 & $3.0 * *$ & $-9.6 * *$ & $15.7 * *$ & $2.2 *$ & $4.2 * *$ & 0.8 & -0.1 \\
\hline Punjab Sarson $\times$ ZN-M-6 & $5.0 * *$ & $-5.0 * *$ & $9.0 * *$ & $-5.1 * *$ & $-3.3 * *$ & -0.5 & 1.7 \\
\hline Legend $\times$ Duncled & $-6.6 * *$ & $-8.0 * *$ & $14.4 * *$ & $-5.1 * *$ & $5.3^{* *}$ & 0.2 & $3.6 * *$ \\
\hline Legend $\times$ K-258 & $2.8 * *$ & 1.1 & -1.8 & $4.3^{* *}$ & 1.3 & 1.1 & 1.4 \\
\hline Legend $\times$ ZN-R-1 & $9.6^{* *}$ & $-6.7 * *$ & $11.8 * *$ & $-3.3 * *$ & -0.7 & -1.5 & 1.3 \\
\hline Legend $\times$ ZN-R- 8 & $-3.7 * *$ & $5.4 * *$ & $-10.9 * *$ & 0.8 & $5.1 * *$ & -0.4 & -0.5 \\
\hline Legend $\times$ ZN-M-6 & $-2.1 *$ & $8.2 * *$ & $-13.5^{* *}$ & $3.3^{* *}$ & $-11.1 * *$ & 0.6 & $-5.7 * *$ \\
\hline Durre-NIFA $\times$ Duncled & 1.5 & 0.0 & -0.4 & 1.7 & $-3.8 * *$ & $-6.6 * *$ & $2.4^{*}$ \\
\hline Durre-NIFA $\times \mathrm{K}-258$ & $2.5^{*}$ & $-5.8 * *$ & $9.5^{* *}$ & $-4.3 * *$ & $-4.0 * *$ & 1.6 & -1.5 \\
\hline Durre-NIFA $\times$ ZN-R-1 & -1.9 & $4.8^{* *}$ & $-8.8 * *$ & $3.8^{* *}$ & $2.8 * *$ & $5.5 * *$ & $-5.6 * *$ \\
\hline Durre-NIFA $\times$ ZN-R-8 & 0.8 & $4.1 * *$ & $-4.8 * *$ & $-3.0 * *$ & $-9.3 * *$ & -0.4 & 0.6 \\
\hline Durre-NIFA $\times$ ZN-M-6 & $-2.9 * *$ & $-3.2 * *$ & $4.6^{* *}$ & 1.8 & $14.4 * *$ & -0.1 & $4.0 * *$ \\
\hline
\end{tabular}

O: Oil; P: Protein; EA: Erucic acid; OA: Oleic acid; GS: Gluco-sinolate; LA: Linoleic acid; LNA: Linolenic acid; *=Significant at level of P $\leq 0.05$, $* *=$ Significant at level of $\mathrm{P} \leq 0.01$

Table 3 Variances due to GCA and SCA and their ratios for seven characters

\begin{tabular}{l|lllllll}
\hline Trait & Oil & Protein & Erucic acid & Oleic acid & Glucosinolate & Linoleic acid & Linolenic acid \\
\hline values & 1.5 & -0.2 & 0.6 & 0.3 & 0.2 & 0.12 & -0.05 \\
\hline
\end{tabular}

\section{Glucosinolate $(\mu \mathrm{mol} / \mathrm{g})$}

In analysis of variance, genotypes, parents, crosses, lines, testers and their interactions ( $\mathrm{L} \mathrm{x} \mathrm{T)}$ notified highly significant $(\mathrm{P} \leq 0.01)$ results. Bradshaw and Wilson (1998) established significant results in inbred lines of brassica for glucosinolate concentration. On the other hand, parents vs. crosses showed non-significant variation. Glucosinolate contents are toxic for health, so, hybrids with negative GCA and SCA effects should be selected. All lines and two testers revealed significant effects of GCA for glucosinolate either in negative or positive direction. Only one Tester "Legend" showed nonsignificant GCA effects for glucosinolate contents.

In the case of specific combining ability effects (Table 2), twelve hybrids out of fifteen showed significant/highly significant effects of SCA for glucosinolate contents. "Durre-NIFA × ZN-M-6" hybrid depicted highest significant effect for GCA in positive direction followed by "Legend $\times$ Duncled". The hybrid "Legend $\times$ ZN-M-6" expressed highest SCA effects in negative direction (11.1) followed by "Durre-NIFA $\times$ ZN-R-8" (-9.3). Turi et al. (2010) conducted his research in Indian mustard in which maximum GCA (-7.27) was showed by line NUM103 followed by NUM113 (-4.92). In case of SCA effects, maximum desirable values revealed by NUM123 x NUM105 (-15.34) followed by NUM103 x NUM124 (13.71).

The range of glucosinolate contents in fifteen Brassica genotypes were $19.3 \mu \mathrm{mol} / \mathrm{g}$ (Punjab Sarson $\times$ Duncled $)$ to $65.5 \mu \mathrm{mol} / \mathrm{g}$ (Durre-NIFA $\times \mathrm{ZN}-\mathrm{R}-1)$ with the mean values of $42.04 \mu \mathrm{mol} / \mathrm{g}$. Noor-Ul-Abideen et al. (2013) evaluated glucosinolate contents ranged from 55.1 to 86.0 $\mu \mathrm{mol} / \mathrm{g}$ with the mean value of $70.7 \mu \mathrm{mol} / \mathrm{g}$. Bhardwaj and Hamama (2000) found nearby the similar results and predicted glucosinolate contents ranged from 37.8 to 77 $\mu \mathrm{mol} / \mathrm{g}$ with average values of $49.2 \mu \mathrm{mol} / \mathrm{g}$ in Brassica napus.

\section{Linoleic acid $(\%)$}

Genotypes, parents, crosses, lines and their interactions ( $\mathrm{L}$ x T) manifested highly significant genetic $(\mathrm{P} \leq 0.01)$ variations. Three female lines showed highly significant effects of GCA and others two lines revealed 
non-significant differences. The highest positive and negative effects of GCA (Table 1) were shown by the female lines "ZN-R-8 and K-258" respectively. Tester (Legend) depicted highly significant result of GCA in positive direction while tester (Punjab Sarson and DurreeNIFA) noticed highly significance GCA effects in negative direction for linoleic acid contents.

According to Table 2, thirteen hybrids showed significant/highly significant effects of SCA for linoleic acid contents. "Legend $\times$ Duncled" hybrid depicted highest significant effect for GCA (9.7) followed by "Punjab Sarson $\times$ ZN-R-1" $(8)$ and "Durre-NIFA $\times$ ZNM-6" (4.1). The hybrid "Punjab Sarson $\times$ Duncled" expressed highest SCA effects in negative direction (-6.1) followed by "Durre-NIFA $\times$ ZN-R-1" $(-5.5)$ and "Punjab Sarson $\times$ K-258" (-3.8).

According to the results the mean values of Linoleic acid in fifteen crosses were $11.16 \%$. The cross 'Punjab Sarson $\times$ Duncled' showed highest $(15.2 \%)$ while 'Punjab Sarson $\times$ K-258' revealed lowest Linoleic acid (9.5\%). Both linolenic and linoleic fatty acids are essential for health but low concentration is essential for oil stability (Turi et al., 2010).

\section{Linolenic acid (\%)}

Genotypes, parents, crosses, lines, testers and their interactions $(\mathrm{L} \times \mathrm{T})$ notified highly significant $(\mathrm{P} \leq 0.01)$ results. Two female lines showed highly significant effects of GCA and others three lines revealed nonsignificant differences. The highest positive and negative effects of GCA were shown by the female lines "K-258 and ZN-R-8" respectively. All testers revealed significant/highly significant effects of GCA either in negative or positive direction for linolenic acid contents.

In the case of specific combining ability effects (Table 2), fifteen hybrids showed significant/highly significant effects of SCA for linolenic acid contents. "Punjab Sarson $\times$ ZN-R-1" hybrid depicted highest significant effect for SCA in positive direction followed by "Durre-NIFA $\times$ ZN-M-6". The hybrid "Punjab Sarson $\times$ Duncled" expressed highest SCA effects in negative direction followed by "Legend $\times$ ZN-M-6". Nasim \& Farhatullah (2013) performed his experiment in Brassica rapa and found significant GCA effects $(0.28$ and -0.25$)$ for two lines ACC-909 and ACC-902. Maximum SCA effect (1.63) was revealed by the hybrid ACC-265 x ACC-403.

High concentration of linolenic fatty acids stimulates the oxidation process which has negative effect on quality and flavor of edible oil. Low percentage of linolenic fatty acids is essential for normal vascular and immunological system control (Burns et al., 2003). Linolenic acid causes rapid oxidation and instability which reduces the shelf life of oil. So, its level must be reduced to promote shelf life of products (Mikolajczyk et al., 2011). According to the results the cross 'Punjab Sarson $\times \mathrm{ZN}-\mathrm{R}-1$ ' showed highest $(9.5 \%)$ while 'Durre-NIFA $\times$ ZN-R-1' revealed lowest linolenic acid contents $(5.4 \%)$. The mean values of fifteen genotypes were $7.87 \%$. Noor-Ul-Abideen et al. (2013) determined the values of linolenic acid content from 8.1 to $9.7 \%$ with mean value of $8.8 \%$ which supported to our results. Ahmad et al. (2012) and Khan et al. (2008) reported similar findings and found the range of linolenic acid contents from 7.65 to $12.86 \%$ and 9 to $11 \%$ respectively. Lavkopr et al. (2006) also described similar results and found linolenic acid from 3.3 to $13.1 \%$ in Brassica cultivars. The range of linolenic acid contents (3.5-14.5\%) determined by Velasco et al. (1999), Ahmad et al. (2008) and Mahmood et al. (2012) that are higher than present results $(5.4-9.5 \%)$.

\section{Variances of GCA and SCA and their ratios}

The variance due to GCA and SCA were estimated for assessing the contribution of the additive and non-additive gene action involved in the inheritance of characters. For most of the traits, the variances of general combining ability were less than that of specific combining ability i.e. the ratios between GCA and SCA were less than unity indicated the presence of dominance genetic effects (Table 3).

In Brassica juncea, Singh et al. (2010) found the additive genetic effect for oil contents. Turi et al. (2010) described the additive genetic action for oil contents, protein, erucic acid, and glucosinolate contents in Brassica juncea that support present studies with respect to oil contents inheritance. Vaghela et al. (2011) depicted the similar results and found dominant role of additive genetic effects for oil content. Nasim and Farhatullah (2013) found the similar findings and described the role of the non-additive genetic effects for oleic acid, erucic acid and linolenic acid in Brassica rapa. Ze-su et al. (2012) calculated the presence of additive genetic effects in rapeseed for erucic acid, oleic acid that are contrast to this study and non-additive for glucosinolate which supported to the present studies.

\section{Conclusion}

The present research evaluated the prominence of nonadditive genetic effects in controlling the quality traits except oil contents. Nasim and Farhatullah (2013) found the role of the non-additive genetic effects for controlling the traits i.e. oleic acid, erucic acid and linolenic acid. Any parent/cross could not prove a common combiner for all the traits which are under study. Line 'Duncled' showed good general combiner for five traits i.e. maximum oil, protein, oleic acid, minimum erucic acid and glucosinolate contents. The tester 'Durree-NIFA' was found good general combiner for maximum protein, minimum erucic acid and linolenic acid contents. The best cross on the basis of specific combining ability effects were 'Legend $\times \mathrm{ZN}-\mathrm{R}-1$ ' for maximum oil contents, "Legend $\times \mathrm{ZN}-\mathrm{M}-6$ " for maximum protein and minimum glucosinolate contents "Punjab Sarson $\times$ Duncled" for minimum erucic acid and linolenic acid contents. The majority of the traits showed non-additive genetic effects except oil contents. The maximum oil contents were found in 'Legend $\times$ ZN-R-1'. 'Punjab Sarson $\times$ Duncled' possessed maximum values of protein and oleic acid contents while minimum for erucic acid and glucosinolates contents. So, these genotypes (line Duncled, tester Durree-NIFA and crosses Legend $\times \mathrm{ZN}$ R-1, Legend $\times$ ZN-M-6, Punjab Sarson $\times$ Duncled) will be used in breeding programme to improve nutritional 
values of Brassica crop and also recommended for general cultivation. It will ultimately increase the accessibility of people toward healthy edible oil.

\section{References}

Ahmad H, Islam M, Khan IA, Ali H, Rahman H, Inamullah. 2008. Evaluation of advance rapeseed line HS-98 for yield attributes and biochemical characters. Pak. J. Bot., 40: 1099-1101.

Ahmad M, Naeem M, Khan IA, Farhatullah, Mashwani MA. 2012. Biochemical quality study of genetically diversified Brassica genotypes. Sarhad J. Agric., 28: 599-602.

Ahsan MZ, Khan FA, Kang SA, Rasheed K. 2013. Combining ability and heterosis analysis for seed yield and yield components in Brassica napus L. J. Biol. Agric. Healthc., 3: 31 36.

Akbar M, Tahira BM, Atta, Hussain M. 2008. Combining ability studies in rapeseed (Brassica napus L.). Int. J. Agric. Biol., 10 205-208.

Amiri-Oghan H, Fotokian MH, Javidfar F, Alizadeh B. 2009. Genetic analysis of grain yield, days to flowering and maturity in oilseed rape (Brassica napus L.) using diallel crosses. Int. J. Pl. Prod., 3: 19-26.

Azizinia S. 2012. Combining ability analysis of yield component parameters in winter rapeseed genotypes (Brassica napus L.). J. Agric. Sci., 4: 87-94.

Bhardwaj HL, Hamama AA. 2000. Oil, erucic acid, and glucosinolate contents in winter hardy rapeseed germplasms. Ind. J. Crops Prod., 12: 33-38.

Bradshaw JE, Wilson RN. 1998. Inbred line versus $F_{1}$ hybrid breeding in Swedes (Brassica napus L. var. Napobrassica Peterm). Plant Br., 113: 206-216.

Burns MJ, Barnes SR, Bowman JG, Clarke MHE, Werner CP, Kearsey MJ. 2003. QTL analysis of an inter-varietal set of substitution lines in Brassica napus: Seed oil content and fatty acid composition. J. Hered., 90: 39-48.

Ceyhan E, Avci MA, Karadas S. 2008. Line $\times$ tester analysis in pea (Pisum sativum L.): Identification of superior parents for seed yield and its components. Afr. J. Biotech., 7: 2810-2817.

El-Beltagi HEl-DS, Mohamed AA. 2010. Variations in fatty acid composition, glucosinolate profile and some phytochemical contents in selected oil seed rape (Brassica napus L.) cultivars. Grasas Y Aceites., 6: 143-150.

Farshadfar E, Kazemi Z, Yaghotipoor A. 2013. Estimation of combining ability and gene action for agro-morphological characters of rapeseed (Brassica napus L.) using line $\times$ tester mating design. Int. J. Adv. Biol. Biom. Res., 1: 711-717.

FAOSTAT. 2012. UN Food \& Agriculture Organization. (http://faostat.fao.org/site/339/ default.aspx 13-06-2015).

Girke A, Schierholt A, Becker HC. 2012. Extending the rapeseed gene pool with resynthesized Brassica napus II: Heterosis. J. Theor. Appl. Genet., 124: 1017-1026.

Jia L, De-sheng M, Yun-chang L, Jia-cheng C, Hui W, Peng-fei P, Li F, Qiong H. 2013. Combining ability and breeding potential of rapeseed elite lines for pod shatter resistance. J. Integr. Agric., 12: 552-555.

Kempthorne O. 1957. An Introduction to Genetic Statistics. John Wiley and Sons Inc, New York.

Khan K, Farhatullah, Khalil IH. 2008. Phenotypic correlation analysis of elite $\mathrm{F}_{3: 4}$ Brassica populations for quantitative and qualitative traits. J. Agric. Biol. Sci., 3: 38-42.

Khan SA, Ahmad H, Khan A, Saeed M, Khan SM, Ahmad B. 2009. Using line $\times$ tester analysis for earliness and plant height traits in Sunflower (Helianthus Annus L). Recent Res. Sci. Tech., 1: 202-206.

Lavkopr RA, Velnerus PL, Ichkolovr OT, Kuc VLR, Oiskohou. 2006. Estimation of fatty acid content in intact seed of oil seed rape (Brassica napus L.) lines using Near-Infra red Spectroscopy. Czech J. Genet. Pl. Breed., 42: 132-136.
Marjanović-Jeromela A, Marinković R, Jocković M, Mitrović P, Milovac Ž, Hristov N, Savić J, Stamenković B. 2014. Evaluation of genetic variance components for some quantitative traits in rapeseed (Brassica napus L.). J. Genetika, 46: $179-185$.

Mikolajczyk K, Bartkowiak-Broda I, Poplawska W, Spasibionek S, Dobrzycka A, Dabert M. 2011. A multiplex fluorescent PCR assay in molecular breeding of oilseed rape. In: Plant Breeding. I.Y. Abdurakhmonov. InTech :Janeza Trdine 9, 51000 Rijeka, Croatia. pp. 185-200.

Muhammad A, Raziuddin, Muhammad A, Raza H, Rahman AU, Ali I. 2014. Combining ability and heritability studies for important traits in $\mathrm{F}_{2}$ of Brassica napus. Int. J. Basic Appl. Sci., 14: 7-11.

Nasim A, Farhatullah. 2013. Combining ability studies for biochemical traits in Brassica rapa (1.) ssp. dichotoma (roxb.) hanelt. Pak. J. Bot., 45: 2125-2130.

Noor-Ul-Abideen S, Nadeem F, Abideen SA. 2013. Genetic variability and correlation studies in Brassica napus $\mathrm{L}$. genotypes. Int. J. Innovat. Appl. Studies, 2:574-581.

Pak. Economic Survey. 2013-14. Ministry of Finance Division, Economic Advisor's wing, Islamabad, Pakistan.

Ping S, Rodney JM, Galwey N, Deve W. 2003. Influence of genotype and environment on oil and protein concentrations of canola (Brassica napus L.) grown across southern Australia. Aust. J. Agric. Res., 54: 397-407.

Panhawar SA, Baloch MJ, Jatoi WA, Veesar NF, Majeedano MS. 2008. Combining ability estimates from line $\times$ tester mating design in upland cotton. Proceeding. Pak. Acad. Sci., 45: 69-74.

Rameeh V. 2011. Line $\times$ tester analysis for seed yield and yield components in spring and winter type varieties of oil seed rape. J. Cereals Oilseeds, 2: 66-70.

Rameeh V. 2012a. Heterosis and heterobeltiosis of yield associated traits in rapeseed cultivars under limited nitrogen application. Agri. J. (Pol'nohospodárstvo), 58: 77-84.

Rameeh V. 2012b. Combining ability analysis of plant height and yield components in spring type of rapeseed varieties (Brassica napus L.) using line $\times$ tester analysis. Int. J. Agric. For., 2: 5862.

Sabaghnia N, Dehghani H, Alizadeh B, Mohghaddam M. 2010. Heterosis and combining ability analysis for oil yield and its components in rapeseed. Aust. J. of crop sci., 4: 390-397.

Saeed A, Chaudhry MA, Saeed N, Khaliq I, Johar MZ. 2001. Line × tester analysis for some morpho-physiological traits in bread wheat. Int. J. Agric. Biol., 3: 444-447.

Singh M, Singh L, Srivastava SBL. 2010. Combining ability analysis in Indian mustard (Brassica juncea L. Czern \& Coss). J. of Oilseed Brassica, 1: 23-27.

Snowdon R, Lühs W, Friedt W. 2007. Brassica Oilseeds. In: Genetic Resources, Chromosome Engineering and Crop Improvement. R.J. Singh. CRC Press Taylor \& Francis Group New York. pp. 195-230.

Steel RGD, Torrie JH, Dickey DA. 1997. Principle and procedure of Statistics: A biometrical approach $\left(3^{\text {rd }}\right.$ Ed.). McGraw Hill Book Int. Co. New York.

Tahira T, Mahmood, Tahir MS, Saleem U, Hussain M, Saqib M. 2011. The estimation of heritability, association and selection criteria for yield components in mustard (Brassica juncea). Pak. J. Agri. Sci., 48: 251-254.

Turi NA, Raziuddin NA, Farhatullah, Khan NU, Munir I, Shah AH, Khan S. 2010. Combining ability analysis in Brassica juncea L. for oil quality traits. Afric. J. Biotech., 9: 3998-4002.

Vaghela PO, Thakkar DA, Bhadauria HS, Sutariya DA, Parmar SK, Prajapati DV. 2011. Heterosis and combining ability for yield and its component traits in Indian mustard (Brassica juncea L.). J. Oilseed Brassica, 2: 39-43.

Ze-su H, Paisan L, Thitiporn M, Ze-hui C, Wen-dong D, Rong T, De-zhen L. 2012. Inheritance of erucic acid, glucosinolate, and oleic acid contents in rapeseed (Brassica napus L.). J. Northeast Agric. Uni., 19: 1-8. 